\title{
DEVELOPMENT OF CANE SUGAR (SACCHARUM OFFICINARUM) PRODUCTION WITH THE PRODUCTION FACTOR APPROACH IN BELANG MANCUNG VILLAGE, KETOL DISTRICT, ACEH CENTRAL REGENCY
}

\author{
Gustina Siregar ${ }^{1}$, Yudha Andriansyah Putra ${ }^{2}$, Dewa Putu Siantara ${ }^{3}$, Indah Indriyani ${ }^{4}$ \\ Universitas Muhammadiyah Sumatera Utara
}

Correspondence Address : Jl. Kapten Muchtar Basri No.3, Glugur Darat II, Kec. Medan Tim., Kota

Medan, Sumatera Utara 20238

\section{E-mail: ${ }^{1}$ siregargustina@umsu.ac.id, 2yudhaandriansyah @umsu.ac.id, \\ 를.}

\begin{abstract}
The goal of this study was to see how much production parameters influenced sugarcane farming in Belang Mancung Village, Ketol District, Central Aceh Regency. The second goal is to determine whether or not the employment of production variables in sugarcane cultivation in Belang Mancung Village, Ketol District, Central Aceh Regency, is effective. The Cobbdouglass analysis method and the price efficiency approach were employed in this study's data analysis. The results of this study show that the computed $\mathrm{F}$ is more than the $\mathrm{F}$ table $(1042,423>2,74)$ with the choice criterion to accept $\mathrm{H} 1$ and reject $\mathrm{H} 0$ simultaneously, based on regression analysis based on the $\mathrm{F}$ test.
\end{abstract}

Keywords: Efficiency, Factors of Production and Sugarcane Production

\section{INTRODUCTION}

Agriculture is one of the primary sectors that support the Indonesian economy, in this era of globalization the agricultural sector plays an important role in the socio-economic structure, because it turns out that the agricultural sector is more resistant to economic crises than other sectors 1 .The average production of sugarcane in the world is around 65 tons per hectare. Compared to world production, Indonesia's sugar production is only $1.68 \%$ and sugar consumed is $2.79 \%$ of the total world sugar consumption. Data from the Central Statistics Agency or BPS (2012) states that the area of sugarcane plantations in Indonesia in 2010 to 2012 tends to decrease. namely $0.37 \%$ to 434.96 thousand hectares, while in 2012 the area of sugarcane plantations in Indonesia increased to 453.32 hectares or about $4.22 \%$, this fluctuating situation has not been able to guarantee the adequacy of sugarcane needs in the form of sugar and molasses of the community. Indonesia in a sustainable manner (Mamet Hakim, 2010) 2.

Ketol District is one of the sub-districts in Central Aceh Regency which has the most extensive potential for sugarcane development. In addition to producing high quality coffee, Central Aceh Regency is also famous as a producer of sugar cane with a very sweet taste. According to data from the plantation sector in Central Aceh, the area of sugarcane plantations in this sub-district currently reaches more than 8000 hectares and is spread across all villages or villages in the Ketol sub-district.

Efficiency is divided into 3, namely technical efficiency, price efficiency, and economic efficiency, technical efficiency can be achieved if farmers are able to allocate production factors in 
such a way that high production can be achieved. Price efficiency will be achieved if farmers get big profits by buying production factors at low prices and selling produce when prices are high. Economic efficiency is achieved if farmers are able to increase their production at pre-production factor prices that can be suppressed, but can sell their production at high prices at the same time 3 .

Ketol District, Central Aceh Regency is a highland area of Gayo people who live or live in Ketol District, the majority as farmers. One of the commodities cultivated there is sugar cane. Based on a preliminary survey conducted in the research area, there are production factors that greatly affect the efficiency of sugarcane farming and farmers' income, such as land area, labor, seeds and fertilizers.

Increased sugarcane production can be achieved if the use of sugarcane production inputs has been used efficiently. If the use of production inputs has been efficient, it will provide high and maximum income for sugarcane farmers in Ketol District, Central Aceh Regency. However, the level of efficiency in the use of production factors in sugarcane farming in Ketol District, Central Aceh Regency is not known for certain. Therefore, the author is interested in conducting a research entitled "Analysis of the Efficiency of the Use of Production Factors in Sugarcane Farming".

\section{IMPLEMENTATION METHOD}

This research method uses case studies, namely research cases that are used by looking directly at the problems that arise in the research area. This research was conducted in Belang Mancung Village, Ketol District, Central Aceh Regency, where sugarcane farming actors became the object of the research population. The method of determining the location of the research was carried out purposively, on the grounds that the Belang Mancung village is one of the villages that has quite a lot of people's sugarcane farming. The sampling method used in this study is simple random sampling, namely the sampling of members of the population is carried out randomly without regard to the strata in the population. The data obtained in this study consisted of primary and secondary data. Primary data was obtained from direct interviews with respondents using a list of questionnaires that had been prepared in advance, while secondary data was obtained from related institutions or agencies such as the agriculture office.

\section{RESULTS AND DISCUSSION}

This study aims to see whether there is an influence between firm size, debt policy, and profitability on firm value.

Tabel 1. Tabel Coefficients

\begin{tabular}{lcclll}
\hline Model & \multicolumn{2}{l}{ Unstandardized Coefficients } & $\begin{array}{l}\text { Standardized } \\
\text { Coefficients } \\
\text { Beta }\end{array}$ & T & Sig. \\
\hline (Constant) & 12,670 &, 122 & & 21,898 &, 000 \\
area of land &, 078 &, 018 &, 073 & 4,430 &, 000 \\
Labor & 1,114 &, 033 & 1,089 & 33,693 &, 000 \\
Seeds &,- 026 &, 022 &,- 030 & $-1,163$ &, 253 \\
Fertilizer &, 051 &, 016 &, 071 & 3,160 &, 003 \\
\hline
\end{tabular}

Primary data was processed in 2020.

Tabel 1 show the value (Constant) $=12,670$ indicates that if the value of land area $(\mathrm{X} 1)$, labor (X2), seeds (X3), and fertilizer (X4) is 0 , then the variable amount of production has a value of 


\section{ORFAI JOURNAL Multidiciplinary Output Research For Actual and International Issue}

$12,670 \mathrm{Kg} / \mathrm{Season} . \mathrm{X} 1$ is the regression coefficient of the land area with a value of 0.078 . This means that if there is an increase in the value of the variable land area by $1 \%$, it will increase the value of the variable amount of production by $0.078 \%$. Seasoning with the assumption that other variables are held constant (cateris paribus). X2 is the regression coefficient of the labor variable with a value of 1.114. This means that if there is an increase in the value of the labor variable by $1 \%$, it will decrease the value of the variable amount of production by $1.114 \%$ per season with the assumption that other variables are considered constant (caterisparibus). X3 is the regression coefficient of the seed variable with a value of -0.026 , meaning that if there is an increase in the value of the seed variable by $1 \%$, it will increase the value of the variable amount of production by $0.026 \%$ per season with the assumption that other variables are considered constant (caterisparibus).

Tabel 2. Simultaneous Test (F Test)

\begin{tabular}{|c|c|c|c|c|c|c|}
\hline \multirow[t]{2}{*}{ Model } & & $\begin{array}{l}\text { Sumof } \\
\text { Squares }\end{array}$ & Df & $\begin{array}{l}\text { Mean } \\
\text { Square }\end{array}$ & $\mathbf{F}$ & Sig. \\
\hline & Regression & 1,907 & 4 & ,447 & 1042,423 &, $000^{\mathrm{b}}$ \\
\hline \multirow[t]{2}{*}{1} & Residual & ,015 & 32 &, 000 & & \\
\hline & & 1,922 & 36 & & & \\
\hline
\end{tabular}

Primary data was processed in 2020.

Tabel 2 show that the f-count value is 1042.423 with this, then the f-table value is 2.63 . From the test results, it has been obtained that the f-count value is greater than the f-table (1042.423 > 2.63), and the decision criteria are accept $\mathrm{H} 1$ and reject $\mathrm{H} 0$. This means that the variables of land area (X1), labor (X2), seeds (X3), and fertilizers (X4), simultaneously have a significant effect on sugarcane farming income.

Tabel 3. Partial Test (t Test)

\begin{tabular}{lrllll}
\hline \multirow{2}{*}{ Model } & \multicolumn{2}{l}{ Unstandardized Coefficients } & $\begin{array}{l}\text { Standardized } \\
\text { Coefficients }\end{array}$ & \multirow{2}{*}{ T } & Sig. \\
\cline { 2 - 4 } & B & Std. Error & Beta & & \\
\hline (Constant) & 12,670 &, 122 & & 21,898 &, 000 \\
$\quad$ area of land &, 078 &, 018 &, 073 & 4,430 &, 000 \\
Labor & 1,114 &, 033 & 1,089 & 33,693 &, 000 \\
Seeds &,- 026 &, 022 &,- 030 & $-1,163$ &, 253 \\
Fertilizer &, 051 &, 016 &, 071 & 3,160 &, 003 \\
\hline
\end{tabular}

Primary data was processed in 2020.

Tabel 3 show the results of the SPSS processing show that there is a relationship between the independent variables partially and the dependent variable. The t-table value with a $95 \%$ confidence level $(\alpha=0.05)$ was 1.68709 . The explanation of the relationship between each variable and the independent variable is as follows:

1. The t-count value for the variable land area (X1) is $4.430>$ the $t$-table value is 1.68709 and the significance is smaller than $0.05(0.000<0.05)$, so it can be concluded that $\mathrm{H} 1$ is accepted and $\mathrm{H} 0$ is rejected, meaning that partially variable land area has a significant effect on the amount of sugarcane farming production in the research area.

2. The t-count value for the labor variable (X2) is 33,693 > the t-table value is 1.68709 and the significance is smaller than $0.05(0.000<0.05)$, so it can be concluded that $\mathrm{H} 1$ is accepted and $\mathrm{H} 0$ is rejected, meaning that partially variable land area has a significant effect on the amount of sugarcane farming production in the research area. 
3. The t-count value for the seed variable $(\mathrm{X} 3)$ is $(-1.163)<\mathrm{t}$-table value 1.68709 and the significance is greater than $0.05(0.253>0.05)$, so it can be concluded that $\mathrm{H} 1$ is rejected and $\mathrm{H} 0$ is accepted, meaning that partially the seed variable has no effect.

4. significant in terms of sugarcane farming output.

5. The $t$-count value for the fertilizer variable $(\mathrm{X} 4)$ is $3.160>$ the $t$-table value is 1.68709 and the significance is smaller than $0.05(0.003<0.05)$, so it can be concluded that $\mathrm{H} 1$ is accepted and $\mathrm{HO}$ is rejected, meaning that partial variable fertilizer has a significant effect on the amount of sugarcane farming production in the research area.

\section{DISCUSSION}

\section{Price Efficiency Using Factors of Production and Land Area}

It is known that the ratio between the Marginal Product Value (NPM) and the cost of land per planting season is 5,062.37 > 1 . It can be concluded that the use of land production inputs is not efficient or $\mathrm{bYPy} / \mathrm{XPx}>1$. So it is necessary to increase the area of production factors land to increase sugarcane farming production in the research area. The development potential can still be implemented because farmers still have enough land to plant sugarcane.

\section{Price Efficiency in the Use of Labor Production Factors}

From the results of the Debt Policy statistical test, there is a significant value of 0.147 . The significant value is greater than the probability value of $0.05(\alpha=5 \%)$ or the value of $0.147>0.05$. The Debt Policy Variable has a tcount of 1.475 with $t$-table $=2.011$. So $t_{\text {count }}<t_{\text {table }}$ it can be concluded that the Debt Policy has no effect on Firm Value. A company is said to be insolvable if the company's total debt is higher than the total assets of the company. Then there will be a negative relationship between leverage and firm value where high debt will make investors careful in investing. Debt has a negative effect on firm value.

\section{The effect of profitability on firm value}

It is known that the ratio between the Marginal Product Value (NPM) and labor costs per planting season is $0.0048<1$. It can be concluded that the use of labor production factors has not been efficient or YPy/XPx $<1$. Potential development can be done by reducing the factors of production of manpower, especially foreign workers who require high costs.

\section{Price Efficiency from Using Seed Production Factors}

It is known that the ratio between the Marginal Product Value (NPM) and the cost of seeds per planting season is $-0.0027<1$. It can be concluded that the use of seed production factors has not been efficient or $\mathrm{YPy} / \mathrm{XPx}<1$. For potential development, it is necessary to reduce seed production factors to increase sugarcane farming production by reducing plant spacing as recommended.

\section{REFERENCES}

Fauzi.2007. Analisis Penggunaan Faktor Produksi Tanaman Tebu Terhadap Pendapatan Petani.Jakarta: Unswagati.

Hakim, Mamet. 2010.Potensi Sumber Daya Lahan Untuk Tanaman Di Indonesia. Jurnal Agricultura. Jakarta.

Hanafie, Rita. 2010. Pengantar Ekonomi Pertanian. CV Andie Offset. Halaman 308. Hanafie, Rita. 2010. Pengantar Ekonomi Pertanian. CV Andie Offset. 
Ditjebun.2013. Direktoral Jendral Perkebunan Tahun 2013.Jakarta:Direktorat Jendral Perkebunan.

Halaman 78.

Soekartawi.2006.Analisis Usahatani.Jakarta. UI Press.

Soekartawi. 2011. Teori Ekonomi Produksi. Rajawali Grapindo. Jakarta.

Sugiyono. 2011. Metode Penelitian Kuantitatif, Kualitatif Dan R\&D. Bandung: Alfabeta.

Nicholson. 2002. Mikro Ekonomi Intermediate. Jakarta: Binarupa Aksara.

Soekartawi. 2003. teori ekonomi produksi dengan pokok bahasan analisis cob douglas. Jakarta. 
Development Of Cane Sugar (Saccharum Officinarum) Production With The Production Factor Approach In Belang Mancung Village, Ketol District, Aceh Central Regency

DOI: $10.54443 /$ morfai.v1i2.149 